\title{
Blast Nursery Tests for Field Resistance of Rice Varieties with Different Genotypes for True Resistance to Blast
}

\author{
Shigehisa Kiyosawa*, Hiroyuki YasudA**, Isao Shintani*** \\ Hitoshi KoIDE**** and Takeshi Morimoto**** \\ 清沢茂久*・安田弘之**・新谷 勲***・小出仁士****・森元 武****: いもち病真性抵 \\ 抗性遺伝子型の異なるイネ品種の圃場抵抗性の畑晚播による検定
}

\begin{abstract}
Eleven rice varieties with and without a resistance gene, $P \boldsymbol{i}$ - $z$, were tested for their blast resistance in two blast nurseries in Takayama, Gifu Prefecture and Inabu, Aichi Prefecture. Disease severity was measured mainly by the number of lesions per plant and the proportion of diseased leaf-area in Takayama and Inabu, respectively. In both cases, field susceptibility was evaluated by estimating the infection rate on each variety. Infection rate was calculated by various methods. A significant varietal difference of infection rates was obtained in an experiment with three or four replications. The highest correlation coefficient between infecton rates of two nursery tests and that between those of the nursery tests and the field test in the previous paper were obtained when the infection rate was calculated using the equation,

$$
r_{x}=\left(\ln \frac{x_{2}}{1-x_{2}}-\ln \frac{x_{1}}{1-x_{1}}\right) /\left(t_{2}-t_{1}\right) \text {. }
$$

A low correlation coefficient was obtained between infection rates measured at different periods, indicating the importance of choice of dates for rating.
\end{abstract}

(Received February 12, 1977)

\section{Introduction}

In the previous paper ${ }^{5)}$, a method for evaluating field resistance of rice varieties with and without a true resistance gene, $P i-z$, was studied in a field test. Infection rate was employed for estimating field susceptibilitya). The field test, however, required a great deal of labor. It is difficult to test a large number of breeding lines for field resistance by the field test. Another simple and useful method is needed for the purpose of practical breeding. In Japan, the blast nursery test has

* National Institute of Agricultural Sciences, Hiratsuka, Kanagawa 254, Japan 農業技術 研究所

** Gifu Agricultural Experiment Station, Gifu

**** Mountainous Region Experiment Farm, Aichi Agricultural Research Center, Inabu, Aichi 愛知県農業総合試験場・山間技術実験農場

a) In many experiments, field resistance has been measured by infection rate, the percentage of disease leaf-area or the number of lesions. This indicates that field susceptibility has been measured, because a higher measured value corresponds to a higher level of susceptibility. 
been widely used for comparing field resistance among the varieties with the same true resistance genotype. This paper deals with methods for evaluating field susceptibility of varieties with different true resistance genotypes by measuring the infection rate in blast nurseries.

\section{Materials and Methods}

Six varieties carrying a resistance gene, $P i-z$, Seinan-mochi 57, Ou 244, Fukunishiki, M. M. 10, Etsunan 96 and Etsunan 111, and five varieties without the $P i-z$ gene, Ginga, K 50, Norin 22, Shin 2 and Norin 6, were used for the test of field resistance.

The tests were carried out in blast nurseries in two locations, Takayama, Gifu Prefecture and Inabu, Aichi Prefecture, by a randomized block design with three and four replications, respectively. Fifty seeds of each variety were sown in a 50 $\mathrm{cm}$ row spaced $15 \mathrm{~cm}$ apart.

Sowing dates were July 9 in Takayama and June 17 in Inabu. Both nurseries were exposed to natural infection. Disease severity was rated mainly in terms of the number of lesions per plant on August 5, 12 and 19 in Takayama, and mainly in the proportion of diseased leaf-area on July 23, August 2, 9, 17 and September 14 in Inabu. Infection rates were calculated by

or

$$
\begin{aligned}
& r_{\mathrm{y}}=\left(\ln \mathrm{y}_{2}-\ln \mathrm{y}_{1}\right) /\left(\mathrm{t}_{2}-\mathrm{t}_{1}\right), \\
& \mathrm{r}_{\mathrm{Y}}=\left(\ln \frac{\mathrm{y}_{2}}{\mathrm{Y}-\mathrm{y}_{2}}-\ln \frac{\mathrm{y}_{1}}{\mathrm{Y}-\mathrm{y}_{1}}\right) /\left(\mathrm{t}_{2}-\mathrm{t}_{1}\right), \\
& \mathrm{r}_{\mathrm{x}}=\left(\ln \frac{\mathrm{x}_{2}}{\mathrm{X}-\mathrm{x}_{2}}-\ln \frac{\mathrm{x}_{1}}{\mathrm{X}-\mathrm{x}_{1}}\right) /\left(\mathrm{t}_{2}-\mathrm{t}_{1}\right),
\end{aligned}
$$

where $y_{2}$ and $y_{1}$ were the number of lesions per plant at times $t_{2}$ and $t_{1}$, respectively, $x_{2}$ and $x_{1}$ were the proportion of diseased leaf-area at times $t_{2}$ and $t_{1}$, respectively, and $\mathrm{Y}$ and $\mathrm{X}$ were their upper limits. Multipoint infection rates $\left(\mathbf{r}_{\mathrm{T}}\right)$ was obtained as a regression coefficient of the $\operatorname{logit}, \ln [y /(Y-y)] a)$ or $\ln [x /(X-x)]$, on time in days, based on three and five ratings in Takayama and Inabu, respectively.

\section{Results}

The increase of the number of lesions in the nursery in Takayama and infection rates calculated from the data are shown in Table 1. In the table, correlation coefficients were calculated between various values. The infection rate $\left(\mathbf{r}_{\mathrm{T}}\right)$ was obtained as a regression coefficient of the logit of lesion number on time in days from ratings at three times. Correlation of these values with infection rates calculated by equation (1) was relatively high for one measured from the data at $t_{I}$ and $t_{I I}\left(r_{y, I, I I}\right)$ and low for one at $t_{I I}$ and $t_{I I I}\left(r_{y, I I, I I I}\right)$. The correlation coefficient between $r_{y, I, I I}$ and $r_{y, I I, I I I}$ was as low as 0.329. In equation (1), the limitation of disease increase by host amount is not considered. The total area of the host expressed as the maximum number of lesions, which can be produced on the host at $t_{I}$, was taken into consideration to know the influence of the limitation by the equation

$$
\mathrm{Y}=\mathrm{y} / \mathrm{x}
$$

a) $B y \ln \frac{y}{Y-y}=\ln \frac{y_{0}}{Y-y_{0}}+r_{T} t$, where $y_{0}$ is the number of lesions at $t=0$. 


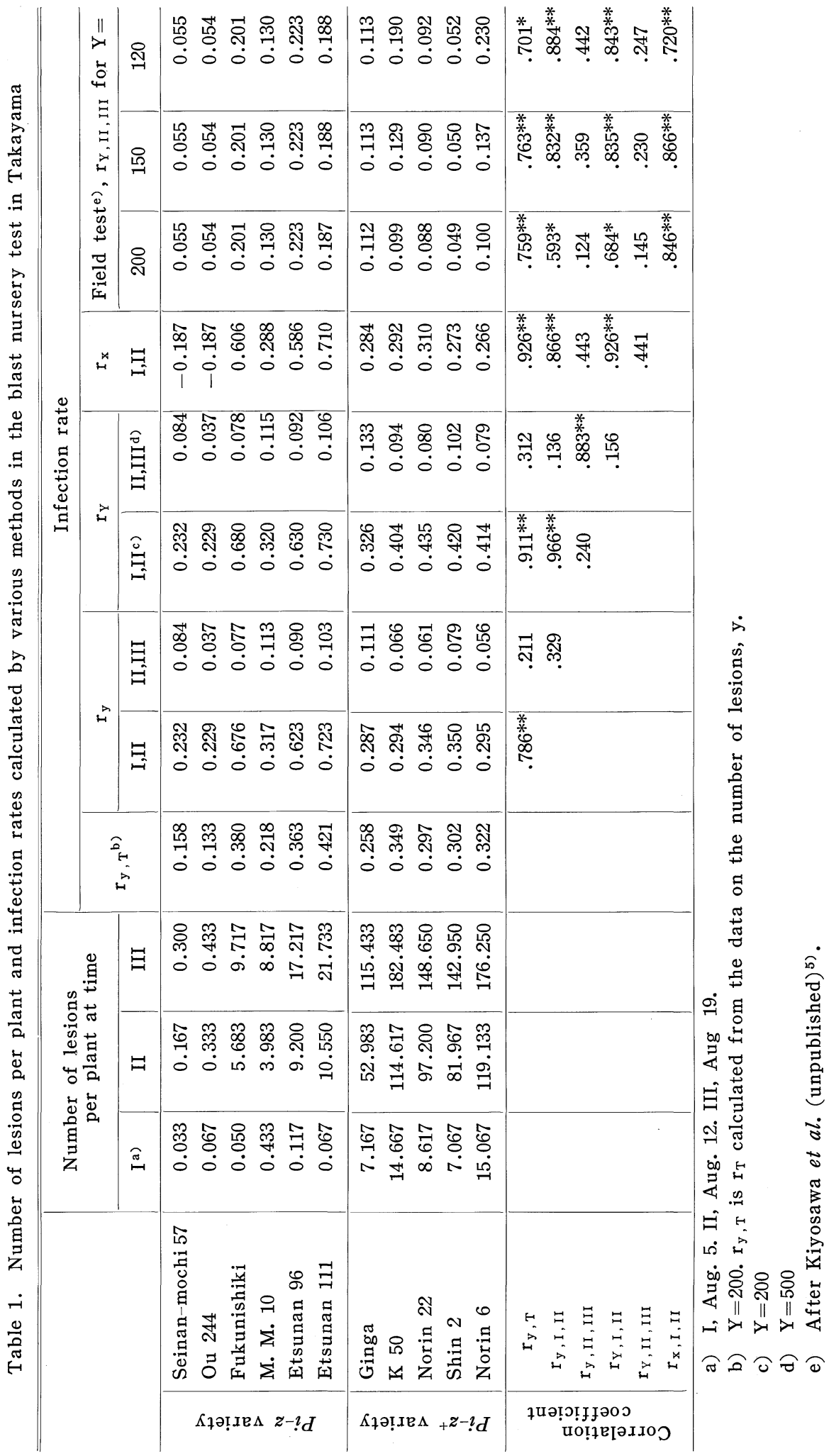




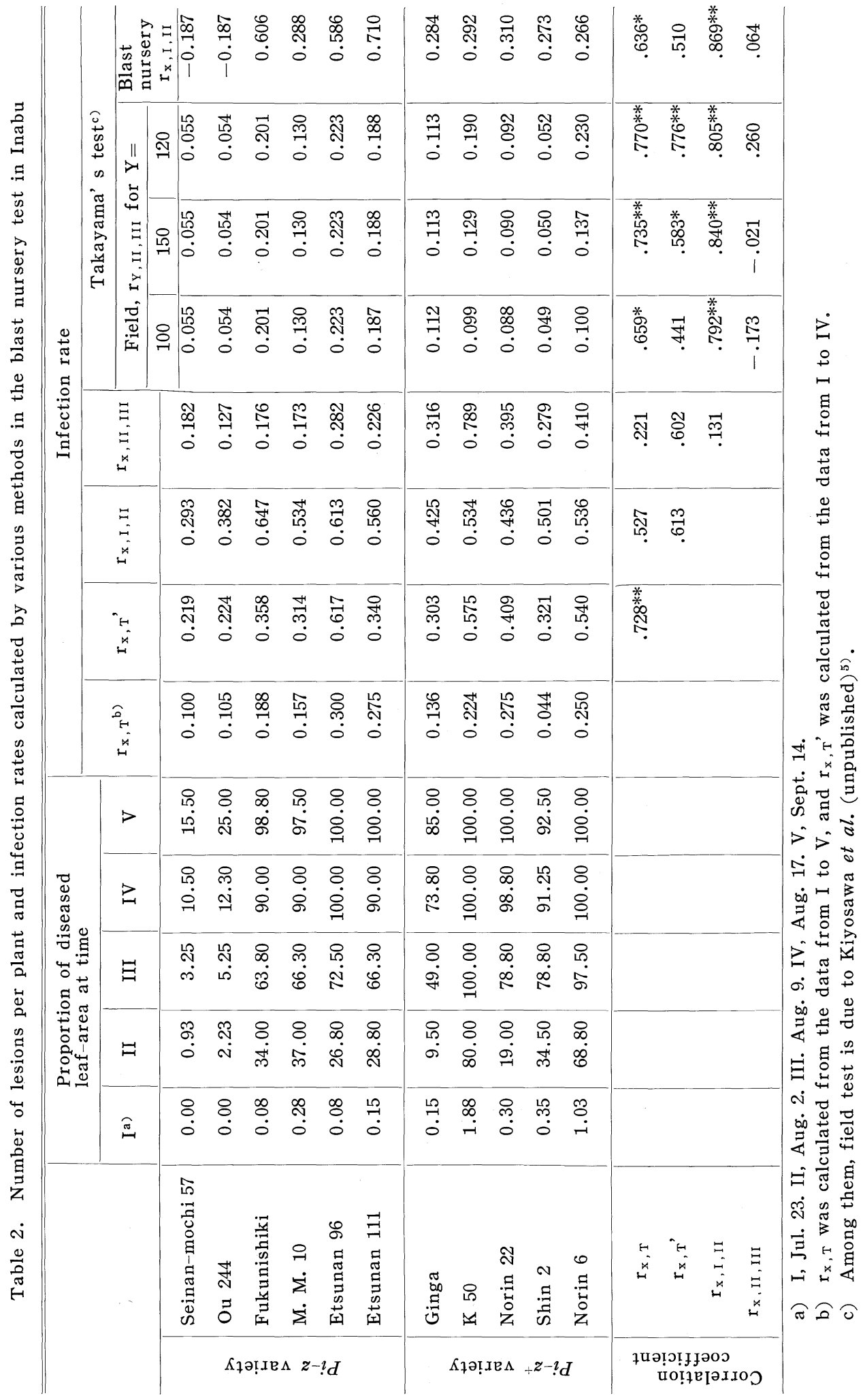


which was proposed by Kiyosawa $e t$ al. ${ }^{5}$ ) The correlation coefficient of $\mathrm{r}_{\mathrm{Y}}$ 's with $\mathrm{r}_{\mathrm{T}}$ increased slightly by this treatment, but correlation coefficient between $r_{Y, I, I}$ and $r_{\mathrm{Y}, \mathrm{II}, \mathrm{III}}$ rather decreased. Which is a better estimate of field susceptibility, $r_{\mathrm{y}}$ or $r_{Y}$ ? To know this point, $r_{y}$ and $r_{Y}$ were compared with the $r_{Y}$ values in the field reported in the previous paper ${ }^{5)}$.

When the ry's were calculated by giving a small Y, 120 , the correlation coefficient of them with $r_{y}$ 's in this test was larger than that with $r_{Y}$ 's in this test. When the ry's in the field were computed for a large Y, 150 or 200, a reverse tendency was found. Similar infection rates were calculated by equation (3) for $X=1$ which was extensively used by van der Plank ${ }^{8)}$. The obtained $r_{x}$ 's showed a high correlation coefficient with $\mathrm{r}_{\mathrm{T}}$ in the nursery and also with $\mathrm{r}_{\mathrm{Y}}$ in the field. The $r_{x}$ 's showed the highest correlation coefficient with the $r_{Y}$ 's in the field for $Y=$ 200 and 150. This suggests that $r_{x, I, I I}$ 's are the most suitable estimate of field susceptibility in the nursery among the measurements used in this study.

The results in the nursery in Inabu were shown in Table 2. Disease increase was measured by the proportion of diseased leaf-area. The correlation coefficient between $r_{x, I, I I}$ and $r_{x, I I, I I}$ was very low also in this case. The correlation coefficient with $r_{x, T}$ in the blast nursery was higher in $r_{x, I, I I}$ than in $r_{x, I I, I I}$. A similar tendency was obtained on $r_{y, T}$ in the field in Takayama. This point agrees with the results obtained in the blast nursery in Takayama.

The highest correlation coefficients were 0.884 between the field and the blast nursery in Takayama, 0.840 between the field in Takayama and the blast nursery in Inabu, and 0.869 between blast nurseries in both locations. These values are sufficiently high. It can be said that sufficiently reliable estimates were obtained to compare varietal difference of field susceptibility in varieties with different genotypes for true resistance.

Variance analyses of the individual results of both blast nursery tests were performed to know reliability of the individual tests, as shown in Table 3. In both tests, significant differences of infection rates between varieties were found. This indicates that reliable data can be obtained on infection rate, $i$. $e$. field susceptibility, through a test in a scale of this extent.

\section{Discussion}

The authors tested the field resistance of varieties with and without the $P i-z$ gene in a field in the previous paper ${ }^{5)}$, and in nurseries in this paper. In the field test, disease increase was measured by the number of lesions per plant, and

Table 3. Mean squares of variance analyses of infection rates measured in the blast nursery tests

\begin{tabular}{l|cc|c}
\hline \multirow{2}{*}{\multicolumn{1}{c}{ Source }} & \multicolumn{2}{|c|}{ Takayama } & \multirow{2}{*}{ Inabu } \\
\cline { 2 - 4 } & $\mathrm{Y}=500$ & $\mathrm{Y}=200$ & \\
\hline Between varieties & $0.054(10)^{* *}$ & $0.052(10)^{* *}$ & $0.070(10)^{* *}$ \\
Between replications & $0.010(2)^{*}$ & $0.015(2)^{*}$ & $0.042(3)^{* *}$ \\
Error & $0.003(20)$ & $0.004(20)$ & $0.009(30)$
\end{tabular}

* and **: Significant at the $5 \%$ and $1 \%$ level, respectively.

( ) : Degrees of freedom. 
infection rate, which is a measure of field susceptibility of varieties, was calculated with or without consideration of host limitation. The results indicated that a consideration of the host limitation increased the correlation coefficient between the infection rates observed at different dates as well as between the infection rates in the field and those observed in the blast nursery. This reveals that the limitation of disease increase by the host amount is functional in the field, and is important in evaluation of field susceptibility especially when the varieties have different genotypes for true resistance.

Such a consideration has generally been taken by logit transformation of the proportion of diseased leaf-area ${ }^{1-4,6-8)}$. In this study, the logit transformation of the proportion of diseased leaf-area, the use of $\ln \frac{x}{1-x}$, gave high correlations between the infection rates in the two nurseries, and also between the infection rates in these nurseries and those calculated by equation (2) in the field.

In the field test, the value $\mathrm{Y}$, the upper limit of disease increase in terms of the number of lesions, which gave the highest correlation coefficient between infection rates in the field and those in other tests, agreed approximately with the maximum number of lesions which could be produced on the plant at that time, as calculated by $\mathrm{y} / \mathrm{x}$. This has an important significance. The value of total leaf-area of a plant divided by the mean area of lesions should be the maximum of the number of lesions which can be produced on the plant after one incubation period.

An important problem was noticed in the measurement of infection rates as a regression coefficient of the logit of the proportion of diseased leaf-area on time in days. There was no correlation between infection rates measured at different dates in both nursery tests. This indicates that an easy use of infection rates is dangerous for estimating field susceptibility, because varietal rank of field susceptibility is generally not expected to vary according to plant stages. The present study showed that early phase of infectious season of the fungus was suitable for estimating field susceptibility by infection rates in the blast nursery. Whether or not this is always true remains to be studied.

Blast nursery tests showed that a significant difference of infection rates could be obtained in the nursery containing three or four replications. On the other hand, the field test in the previous paper ${ }^{5)}$ showed that three replications were not sufficient to obtain a significant difference of infection rates. This does not necessarily indicate that the blast nursery test is a better method to estimate field susceptibility or resistance than the field test. There is, however, no sufficient evidence at least in literature that the results in the blast nursery test are always parallel to the results in the field test. Studies must be continued to establish a better method to get a parallel relation to the situation in the farmer's field.

\section{Literature cited}

1. Asai, Y., Kiyosawa, S. and Morimoto, T. (1974). Res. Bull. Aichi-ken Agr. Res. Cent. A7:41 -54. (In Japanese)

2. Ayers, J. E., Nelson, R. R., Castor, L. L. and Blanco, H. (1976). Plant Dis. Reptr. 60 : 331335.

3. Berger, R. D. (1975). Phytopathology $65: 485-487$.

4. Fry, W. E. (1975). Phytopathology $65: 908-911$.

5. Kiyosawa, S., Yasuda, H. and Shintani, I. (1977). Ann. Phytopath. Soc. Japan. 43 : 508-516

6. MacKenzie, D. R. (1976). Phytopathology $66: 55-59$. 
7. Schenck, N. C. and Stelter, T. J. (1974). Phytopathology $64: 619-624$.

8. Van der Plank, J. E. (1963). Plant Diseases : Epidemics and Control. Academic Press, New York and London, pp. 349.

和 文 摘 要

いもち病真性抵抗性遺伝子型の異なるイ

ネ品種の煵場抵抗性の畑晚播による検定

$$
\begin{aligned}
& \text { 清沢茂久・安田弘之・新谷 勲 } \\
& \text { 小出仁士・㷊元 武 }
\end{aligned}
$$

$P i-z$ 遺伝子をもつ品種ともたない品種とのいもち病に対する 圃場抵抗性を岐皁県高山市と愛知県北設楽郡 稲武町に㧍いて畑晚播で検定した。高山市では個体当り病斑数を，稲武町では病斑面積率を主として調へ， それらから種々の方法で伝染速度を測定した。同じ畑晚播実験で異なる時期に測定した 伝染速度の間の相関 係数は必ずしあ高くなく，2 点で伝染速度を測定する場合，時期の選択に問題のあるととを示した。 2 個所 の実験の伝染速度の間で最も高い相関係数は $\mathrm{r}_{\mathrm{x}}=\left(\ln \frac{\mathrm{x}_{2}}{1-\mathrm{x}_{2}}-1 \mathrm{n} \frac{\mathrm{x}_{1}}{1-\mathrm{x}_{1}}\right) /\left(t_{2}-t_{1}\right)$ にり計算された場合にえ られ，乙の場合前報の本田での結果との相関む最も高かった。この方法で伝染速度を計算するとき， 3 ある いは 4 区制の実験で伝染速度に有意な品種間差異がえられた。 